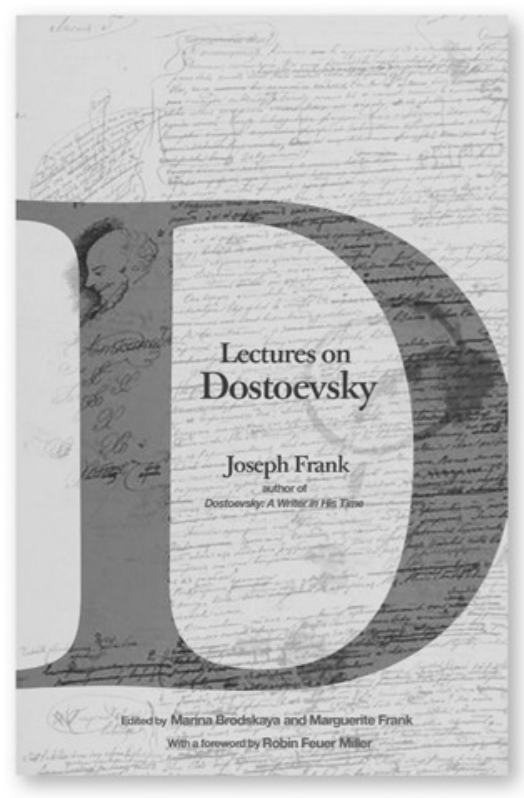

From the author of the definitive biography of Fyodor Dostoevsky, never-before-published lectures that provide an accessible introduction to the Russian writer's major works

"Remarkably informative and clear, this book presents the results of Joseph Frank's decades-long research on Dostoevsky's writings in a condensed and accessible form." -Barry Scherr, Dartmouth College

Cloth $\$ 29.95$

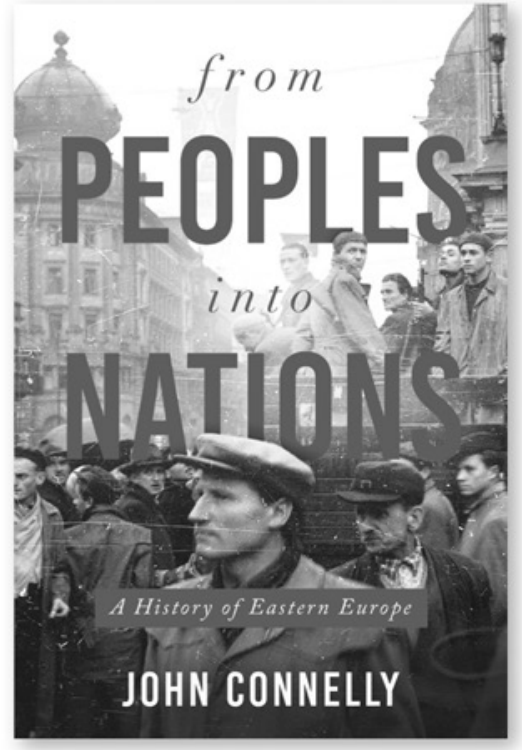

A sweeping narrative history of Eastern Europe from the late eighteenth century to today

"The work of a skilled historian at the peak of his scholarly powers, From Peoples into Nations will no doubt be discussed and debated within the field-and beyondfor years to come." - Holly Case, author of The Age of Questions Cloth $\$ 35.00$ 


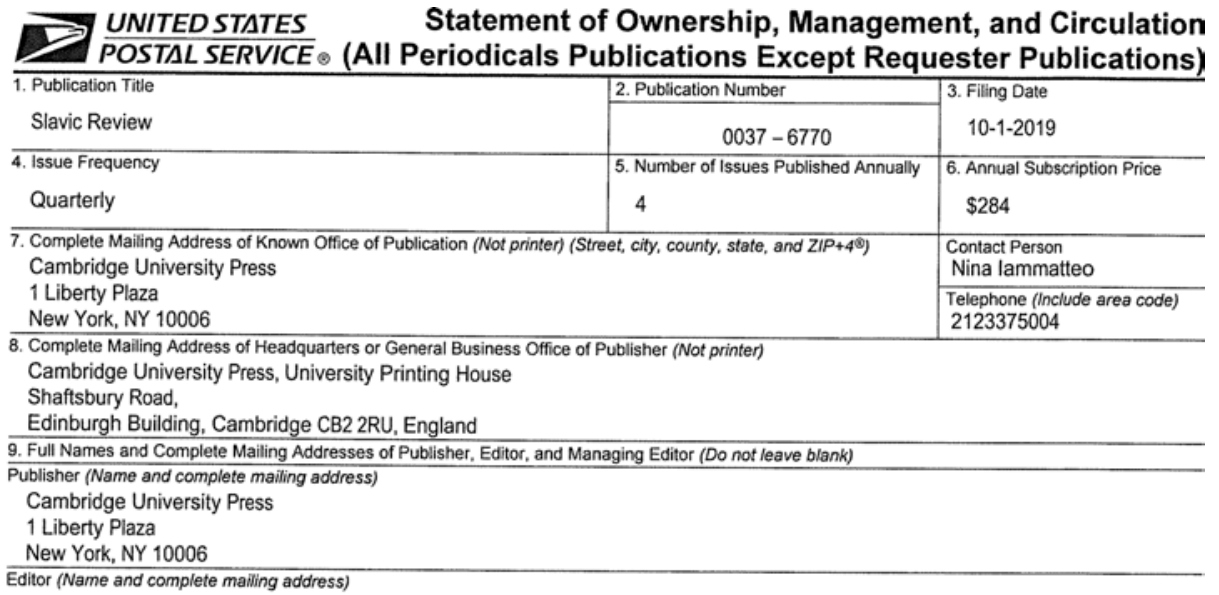

Harriet Murav, University of Illinois, 1207 W.Oregon St.,Urbana, IL 61801-3716

Managing Editor (Name and complete mailing address)

Dmitry Tartakovsky,University of Illinois, 1207 W.Oregon St., Urbana, IL 61801-3716

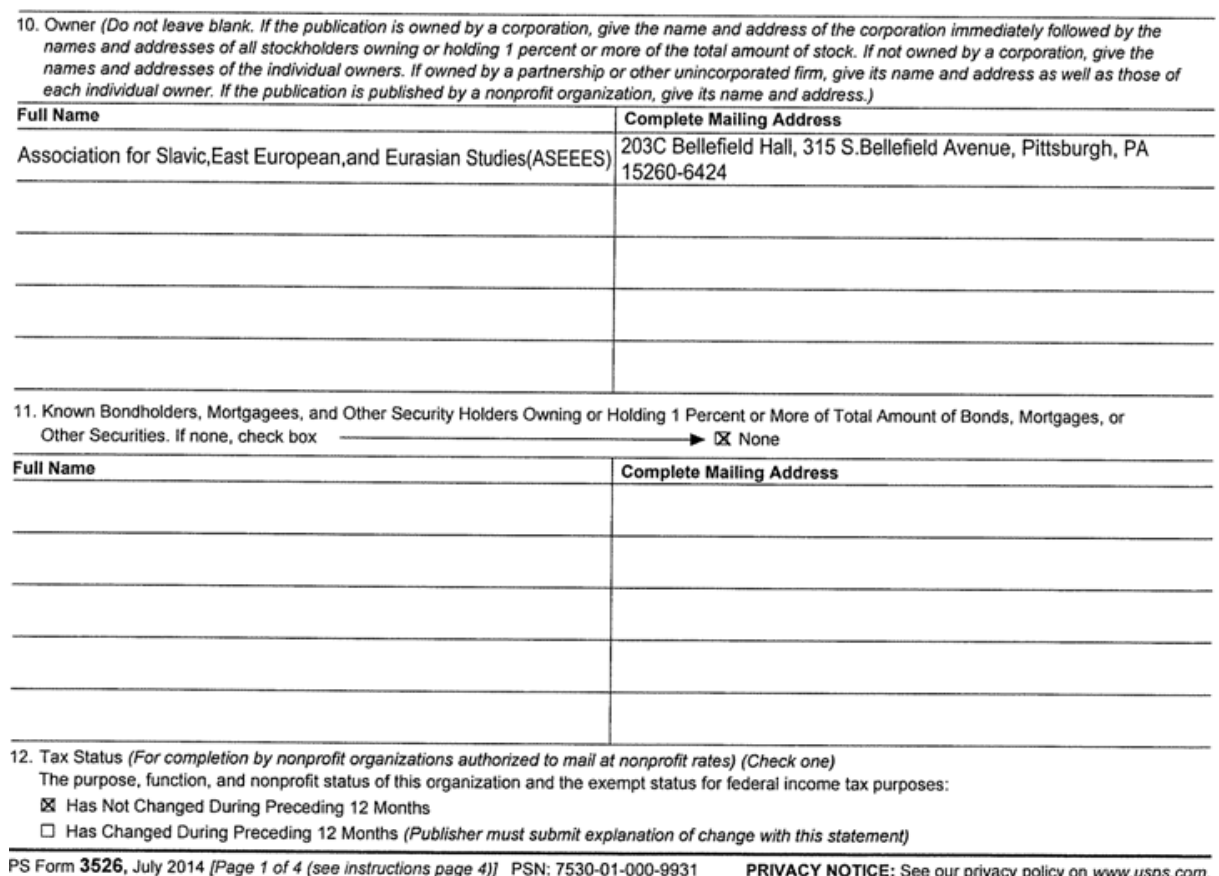




\begin{tabular}{|c|c|c|c|c|}
\hline \multicolumn{3}{|c|}{$\begin{array}{l}\text { 13. Publication Title } \\
\text { Slavic Review }\end{array}$} & \multicolumn{2}{|c|}{$\begin{array}{l}\text { 14. Issue Date for Circulation Data Below } \\
\text { JUNE } 2019\end{array}$} \\
\hline \multicolumn{3}{|c|}{ 15. Extent and Nature of Circulation } & \begin{tabular}{|l|} 
Average No. Copies \\
Each Issue During \\
Preceding 12 Months
\end{tabular} & $\begin{array}{l}\text { No. Copies of Single } \\
\text { Issue Published } \\
\text { Nearest to Filing Date }\end{array}$ \\
\hline \multicolumn{3}{|c|}{ a. Total Number of Copies (Net press run) } & 2151 & 2193 \\
\hline \multirow{4}{*}{$\begin{array}{l}\text { b. Paid } \\
\text { Circulation } \\
\text { (By Mail } \\
\text { and } \\
\text { Outside } \\
\text { the Mail) }\end{array}$} & (1) & $\begin{array}{l}\text { Mailed Outside-County Paid Subscriptions Stated on PS Form } 3541 \text { (Include paid } \\
\text { distribution above nominal rate, advertiser's proof copies, and exchange copies) }\end{array}$ & 1659 & 1449 \\
\hline & (2) & $\begin{array}{l}\text { Mailed In-County Paid Subscriptions Stated on PS Form } 3541 \text { (Include paid } \\
\text { distribution above nominal rate, advertiser's proof copies, and exchange copies) }\end{array}$ & 0 & 0 \\
\hline & (3) & $\begin{array}{l}\text { Paid Distribution Outside the Mails Including Sales Through Dealers and Carriers, } \\
\text { Street Vendors, Counter Sales, and Other Paid Distribution Outside USPS }\end{array}$ & 271 & 246 \\
\hline & (4) & $\begin{array}{l}\text { Paid Distribution by Other Classes of Mail Through the USPS } \\
\text { (e.g.. First-Class Maile) }\end{array}$ & 0 & 0 \\
\hline \multicolumn{3}{|c|}{ c. Total Paid Distribution [Sum of 15b (1), (2), (3), and (4)] } & 1930 & 1695 \\
\hline \multirow{4}{*}{$\begin{array}{l}\text { d. Free or } \\
\text { Nominal } \\
\text { Rate } \\
\text { Distribution } \\
\text { (By Mail } \\
\text { and } \\
\text { Outside } \\
\text { the Mail) }\end{array}$} & (1) & Free or Nominal Rate Outside-County Copies included on PS Form 3541 & 0 & 0 \\
\hline & (2) & Free or Nominal Rate In-County Copies Included on PS Form 3541 & 0 & 0 \\
\hline & (3) & $\begin{array}{l}\text { Free or Nominal Rate Copies Mailed at Other Classes Through the USPS } \\
\text { (e.g., First-Class Mail) }\end{array}$ & 0 & 0 \\
\hline & (4) & Free or Nominal Rate Distribution Outside the Mail (Camiers or other means) & 2 & 2 \\
\hline \multicolumn{3}{|c|}{ e. Total Free or Nominal Rate Distribution (Sum of 15d (1), (2), (3) and (4)) } & 2 & 2 \\
\hline \multicolumn{3}{|c|}{ f. Total Distribution (Sum of $15 \mathrm{c}$ and $15 e$ ) } & 1932 & 1697 \\
\hline \multicolumn{3}{|c|}{ g. Copies not Distributed (See instructions to Publishers \#4 (page \#3)) } & 219 & 496 \\
\hline \multicolumn{3}{|c|}{ h. Total (Sum of $15 \mathrm{f}$ and $g$ ) } & 2151 & 2193 \\
\hline \multicolumn{3}{|c|}{$\begin{array}{l}\text { i. Percent Paid } \\
\text { (15c divided by } 15 \mathrm{f} \mathrm{times} \mathrm{100)}\end{array}$} & $99.9 \%$ & $99.88 \%$ \\
\hline \multicolumn{5}{|c|}{ PS Form 3526, July 2014 (Page 2 of 4) } \\
\hline \multicolumn{3}{|c|}{ 16. Electronic Copy Circulation } & $\begin{array}{l}\text { Average No. Copies } \\
\text { Each Issue During } \\
\text { Preceding } 12 \text { Months }\end{array}$ & $\begin{array}{l}\text { No. Copies of Single } \\
\text { Issue Published } \\
\text { Nearest to Filing Date }\end{array}$ \\
\hline \multicolumn{5}{|c|}{ a. Paid Electronic Copies } \\
\hline \multicolumn{5}{|c|}{ b. Total Paid Print Copies (Line 15c) + Paid Electronic Copies (Line 16a) } \\
\hline \multicolumn{5}{|c|}{ c. Total Print Distribution (Line 15f) + Paid Electronic Copies (Line 16a) } \\
\hline d. Percent Paic & $d(B$ & 3oth Print \& Electronic Copies) ( $16 \mathrm{~b}$ divided by $16 \mathrm{c} \times 100$ ) & & \\
\hline
\end{tabular}

$\square$ I certify that $50 \%$ of all my distributed copies (electronic and print) are paid above a nominal price.

17. Publication of Statement of Ownership

$\square$ If the publication is a general publication, publication of this statement is required. Will be printed in the Winter issue of this publication. 
Membership Dues: students $-\$ 35.00$; those with salaries under $\$ 30,000-\$ 55.00 ; \$ 30,000-$ \$39,999-\$70.00; \$40,000-\$49,999-\$85.00; \$50,000-\$59,999-\$115.00; \$60,000-\$74,999$\$ 135.00 ; \$ 75,000-\$ 99,999-\$ 155.00 ; \$ 100,000-\$ 124,999-\$ 180.00 ; \$ 125,000$ and over$\$ 200.00$. Joint members with one subscription to Slavic Review, add $\$ 40.00$ to dues of higher paid member. For members living outside of the United States please add $\$ 15.00$ for shipping. Subscriptions without membership are: for Electronic-Only, \$290/£188; for Electronic+Print, \$348/£226; for Print only, \$314/£204. Single current and back issues to subscribers are \$60.00; for ASEEES members, $\$ 25.00$ each, plus shipping. Correspondence regarding Slavic Review subscriptions should be sent to Cambridge University Press at: subscriptions_newyork@cambridge.org for information; all others should contact journals@cambridge.org.Correspondence regarding membership, news items for NewsNet, or changes of address should be sent to ASEEES, 203C Bellefield Hall, 315 S. Bellefield Ave., Pittsburgh, PA 15260-6424. Telephone: (412) 648-9911; fax: (412) 648-9815; e-mail: aseees@pitt.edu; website: www.aseees.org. The editors assume no responsibility for statements of fact or opinion made by contributors.

Institutional subscriptions can be purchased direct from Cambridge University Press or through any major subscription agent. Print-only, online-only and bundled print and online prices are all available, and subscription prices are tiered according to institution type and size. Please contact Cambridge University Press for further details. For customers in North America, email: subscriptions_newyork@cambridge.org; or phone: (800) 872-7423, option 4. For customers outside of North America, email: journals@cambridge.org; phone: +44 (0)122332-6070; or fax: +44 (0)1223-32-5150.

Copyright (C) 2020 Slavic Review ISSN 0037-6779 by the Association for Slavic, East European, and Eurasian Studies, Inc. Permission to reprint must generally be obtained from Cambridge University Press. Copying is permitted in accordance with the fair use guidelines of the U.S. Copyright Act of 1976. The association permits the following additional educational uses without permission or payment of fees: academic libraries may place materials from Slavic Review on reserve (in multiple photocopied or electronically retrievable form) for students enrolled in specific courses; teachers may reproduce or have reproduced multiple copies (in photocopied or electronic form) for students in their courses. Those wishing to reproduce material from Slavic Review for any other purpose (general distribution, advertising or promotion, creating new collective works, resale, etc.) must obtain permission from Cambridge University Press. Permissions and reproduction policies, request forms, and contacts are available at: http:// www.cambridge.org/uk/information/rights/permission.htm.

Slavic Review is indexed in ABSEES (American Bibliography of Slavic and East European Studies). Articles appearing in this journal are abstracted or indexed in Historical Abstracts, America: History and Life, ABC Pol Sci: A Bibliography of Contents, Academic Index, Arts and Humanities Citation Index, Linguistic Bibliography, Book Review Index, Historical Abstracts, Humanities Index, MLA, PAIS, RILM, Social Science Index, Social Science Citation Index, Current Contents/Social and Behavioral Sciences, International Bibliography of the Social Sciences, and CrossRef.

The Editorial Office of the Slavic Review is located at the University of Illinois, UrbanaChampaign, and is supported by the College of Liberal Arts and Sciences, the Russian, East European, and Eurasian Center, the Department of Slavic Languages and Literatures, and the Humanities Council.

Articles, books for review, and correspondence concerning editorial matters should be sent to Slavic Review, University of Illinois, 1207 W. Oregon St., Urbana, IL 61801-3716. Telephone: (217) 333-3621; e-mail: slavrev@illinois.edu; website: www.slavicreview.illinois.edu. To advertise in the journal please email USAdSales@cambridge.org or telephone +1(212) 337-5053 in the USA, Canada, or Mexico; email ad_sales@cambridge.org or telephone +44 (1223) 325083 in the rest of the world.

Before submitting manuscripts to Slavic Review, please consult the Information tab on our website for details on criteria, acceptable length, and preparation of the manuscript, available at http://www.slavicreview.illinois.edu/info/manuscripts.html.

Slavic Review does not ordinarily accept unsolicited book reviews. Please consult us if you would like to propose a book for review or a review essay. Slavic Review publishes signed letters to the editor by individuals with educational or research merit. For more detailed policy statements on manuscript submissions, book reviews, and letters to the editor, see our website. 


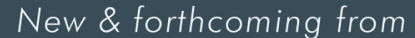 \\ \$ ACADEMIC STUDIES PRESS}

www.academicstudiespress.com

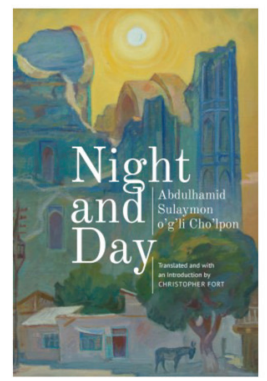

\section{Night and Day}

ABDULHAMID SULAYMON O'G'LI CHO'LPON |Translated by Christopher Fort Central Asian Literatures in Translation November 2019 | 292 pp.; 2 illus. | 9781644690475 | \$26.95 | Paper

Night and Day, an unfinished dilogy by Uzbek author Cho'lpon, follows the terrible fate of a young Uzbek girl condemned to marry a sexual glutton. The novel raises questions about the nature of Russian colonialism, resistance to it, and the intentions of the author, whose life was lost to Stalinist terror.

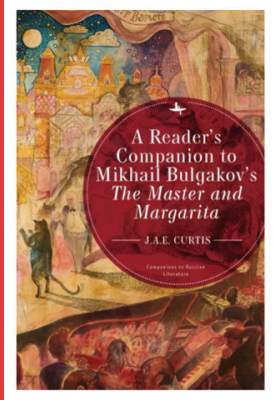

\section{A Reader's Companion to Mikhail Bulgakov's The Master and Margarita}

J. A. E. CURTIS

Companions to Russian Literature December 2019 | 192 pp. | 9781644690789 | \$29.95 | Paper

Readers are often left tantalized and uncertain how to understand the rich meanings of Mikhail Bulgakov's comic and beautiful novel The Master and Margarita, set in Stalin's Moscow. To what extent is it political? Or religious? And how should we interpret the Satanic Woland? This companion guides the readers through the work's thematic, structural and linguistic complexities.

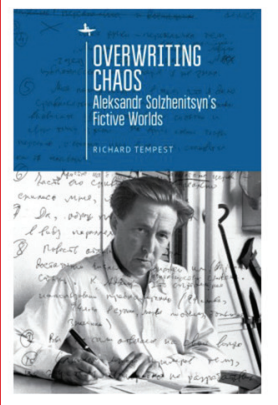

\section{Overwriting Chaos}

Aleksandr Solzhenitsyn's Fictive Worlds

RICHARD TEMPEST

Cultural Revolutions: Russia in the Twentieth and Twenty-First Centuries December 2019 | 742 pp. | 9781644690123 | \$159 | Cloth

A study of Aleksandr Solzhenitsyn's prose that examines his most important characters as well as his treatment of Lenin, Stalin, and the Russian revolution; surprising predilection for literary puzzles and games; erotic themes; and polemical interactions with Russian and Western modernism.

BETWEEN ROME AND BYZANTTUM The Golden Age of the Grand Duchy of Lithuania's

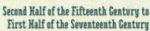
Jürate Kiaupiené

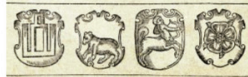

\section{Between Rome and Byzantium}

The Golden Age of the Grand Duchy of Lithuania's Political Culture JÜRATÉ KIAUPIENE | Translated by Jayde Will

Lithuanian Studies without Borders January 2020 | 278 pp. | 9781644691465 | \$119| Cloth

The focus of this book is the unique socio-political and socio-cultural community of the Grand Duchy of Lithuania from the late fifteenth to the early seventeenth century. This ethnically diverse, multilingual, multi-faith, multicultural national space has had a great impact on the socio-political development of Central Europe. 